\title{
Expression of TrkB Receptor Isoforms in the Developing Avian Visual System
}

\author{
Andrew S. Garner, ${ }^{1}$ Harry J. Menegay, ${ }^{1}$ Kristen L. Boeshore, ${ }^{1}$ Xiao-Yi Xie, ${ }^{1}$ James M. Voci, ${ }^{1}$ James E. \\ Johnson, ${ }^{2}$ and Thomas $H$. Large ${ }^{1}$ \\ ${ }^{1}$ Department of Neurosciences, Case Western Reserve University School of Medicine, Cleveland, Ohio 44106-4975, and \\ 2Department of Neurobiology and Anatomy, Bowman Gray School of Medicine of Wake Forest University, Winston- \\ Salem, North Carolina 27157
}

The expression of novel TrkB receptor transcripts has been characterized to understand the potentially diverse roles of brain-derived neurotrophic factor (BDNF) in the developing avian visual system. In situ localization with an extracellular domain probe common to all TrkB transcripts labeled a subpopulation of large retinal ganglion cells as well as many associated visual nuclei, including the neuronal layers within the tectum that receive retinal innervation. Because of the potential for structurally and functionally distinct receptors derived from the TrkB gene locus, cDNA cloning and reverse transcriptionPCR analysis were used to further analyze receptor isoform expression in the retina and tectum. Receptor isoforms were sequenced that contained a deletion of the $\mathrm{N}$ terminus, a deletion in the putative ligand-binding domain, or a deletion in the cytoplasmic juxtamembrane (JM) domain. Two novel JM insertion sequences also were identified, one of which exhibits weak homology to $\beta$-actin and was found in both kinasecontaining $(T K+)$ and kinase deletion $(K D)$ receptor isoforms. In the developing retina, TK+ receptor $\mathrm{MRNA}$ is upregulated during the period of retinal ganglion cell (RGC) death, consistent with the proposed role of BDNF as a tectal-derived survival factor for RGCs. However, the expression of TK+ transcripts in the tectum indicates that this structure also contains cells responsive to BDNF throughout development. Because BDNF is expressed in both the retina and tectum, it is conceivable that TrkB also mediates autocrine/paracrine signaling within these structures or anterograde retinotectal trophic support.

Key words: TrkB receptor; alternative splicing; visual system; retina; tectum; chicken
The vertebrate visual system is an important model for studying the epigenetic signals that guide CNS development. Retroviral tagging (Wetts and Fraser, 1988; Turner et al., 1990) and retinal culture experiments (Reh and Tully, 1986; Guillemot and Cepko, 1992) indicate that extracellular (EC) signals direct the ordered differentiation of retinal cell types from a common multipotent progenitor. The topographic innervation of the avian optic tectum by retinal ganglion cells (RGCs) appears to be partly determined by substrate-bound cues (Drescher et al., 1995), although soluble growth factors also are likely to play important roles within the tectal target fields (Mey and Thanos, 1992). Finally, the survival of neurons in the visual system is dependent on trophic support during development. In the embryonic chick, ablation of the tectum increases RGC death (Rager and Rager, 1978; Hughes and McLoon, 1979), and enucleation increases the death of neurons in the isthmo-optic nucleus (ION), which projects centrifugally to the retina (Clarke ct al., 1976). Enuclcation also lcads to increased death in the tectum (Kelly and Cowan, 1972), indicating that anterograde, as well as retrograde, trophic support must be important for visual system development (see also Clarke, 1985).

Growth factors are an important class of EC molecules likely to

Received June 14, 1995; revised Nov. 21, 1995; accepted Nov. 28, 1995.

This work was supported in part by an MSTP Fellowship (A.S.G.), Northeast Ohio Heart Association Fellowship (X.-Y.X.), and NIH Grants AG00533 (J.M.V.), EY0885 (T.H.L.), and CA60171 (T.H.L.). We thank Dalia Elkhairi for help in the initial library screening and sequencing of TrkB clones.

Correspondence should be addressed to Dr. Thomas H. Large, Department of Neurosciences, CWRU School of Medicine, 2109 Adelbert Avenue, Cleveland, OH 44106-4975.

Copyright (C) 1996 Society for Neuroscience $0270-6474 / 96 / 161740-13 \$ 05.00 / 0$ regulate many aspects of visual system development. Brainderived neurotrophic factor (BDNF), a member of the neurotrophin gene family, has been proposed to be a target-derived factor supporting RGC survival in amphibian (Cohen-Cory and Fraser, 1994), avian (Rodriguez-Tebar et al., 1989), and mammalian (Johnson et al., 1986) species. BDNF mRNA is expressed in the optic tectum during the period of RGC death (Xie et al., 1992; Cohen-Cory and Fraser, 1994; Herzog et al., 1994), and exogenous BDNF supports the survival of RGCs in vitro Johnson et al., 1986; Rodriguez-Tebar et al., 1989) and in vivo after injury (Mey and Thanos, 1993; Voci et al., 1993; Mansour-Robaey et al., 1994). Consistent with this, the principal receptor for BDNF, TrkB, is expressed in the retina (Jelsma et al., 1993; Takahashi et al., 1993; Allendoerfer et al., 1994; Escandon et al., 1994; Okazawa et al., 1994b) and has been localized to mammalian (Jelsma et al., 1993) and amphibian (Cohen-Cory and Fraser, 1994) RGCs. However, BDNF also is expressed in the avian (Herzog and Barde, 1994; Herzog et al., 1994) and amphibian (Cohen-Cory and Fraser, 1994) retina, suggesting that the actions of BDNF are likely to be substantially more diverse than simply mediating target support of RGC survival.

To understand the potential roles of BDNF in the developing avian visual system, it is important to identify the cell types bearing TrkB receptors. In situ hybridization identified a subpopulation of RGCs that express TrkB mRNA, as well as surprisingly strong expression in cells of the optic tectum and many other associated visual nuclei. However, such an analysis is complicated by the fact that alternative splicing of the TrkB gene locus generates a variety of receptor isoforms (Klein et al., 1990; Middle- 
mas et al., 1991) that may differ in ligand-binding (Clary and Reichardt, 1994) and ligand-signaling functions (Lamballe et al., 1993; Tsoulfas et al., 1993; Valenzuela et al., 1993; Garner and Large, 1994). Therefore, we also have characterized the structure of the major TrkB receptor splice variants, many of which are novel. The results of reverse transcription (RT)-PCR analysis of the developmental expression of kinase-containing $(\mathrm{TK}+)$ and kinase deletion (KD) receptor isoforms are consistent with the proposed role for BDNF in the survival of RGCs. However, the early expression of TK + TrkB transcripts in the optic tectum indicates BDNF may play additional roles as an anterograde retinotectal factor and an autocrine/paracrine factor.

\section{MATERIALS AND METHODS}

Animals. Fertilized White Leghorn chicken eggs and 6-week-old chickens were obtained from either Hubbard Farms (Statesville, NC), or Squire Valleevue Farm (Gates Mills, OH). Eggs were staged (Hamburger and Hamilton, 1951) at the time of embryo removal for either in situ analysis or RNA extraction.

Isolation of TrkB receptor splice variants. An embryonic day 13 (E13) chick brain cDNA library in $\lambda \mathrm{gt} 10$ (generously provided by Dr. Barbara Ranscht, La Jolla (CA) Cancer Research Foundation) was screened with a probe corresponding to the middle third of the mouse TrkB cDNA (nucleotides 1181-1785; ATCC) using methods reported previously (Large et al., 1989). Briefly, library lifts on Biotrans membranes (ICN, Costa Mesa, CA) were UV-crosslinked and hybridized overnight at $65^{\circ} \mathrm{C}$ with a ${ }^{32} \mathrm{P}$-labeled riboprobe in hybridization $(\mathrm{HYB})$ buffer containing $5 \times$ SSPE, $5 \times$ Denhardt's, $100 \mu \mathrm{g} / \mathrm{ml}$ denatured herring sperm DNA, and $0.1 \%$ SDS. Final washes of the filters were performed in $2 \times$ SSPE and $0.1 \%$ SDS at $65^{\circ} \mathrm{C}\left(40^{\circ} \mathrm{C}\right.$ below the Tm of a perfect match). The initial screen yielded three TrkB clones and a single TrkC clone (Garner and Large, 1994). Subsequent screens of the library with the longest TrkB clone produced an additional eight TrkB clones, including three clones with complete coding sequenec (sce Fig. 6). cDNA inserts were subcloned into pBluescript SK II + (Stratagene, La Jolla, CA) for singlestranded sequencing in both directions by the Sanger-dideoxy chain termination method (Sequenase, USB, Cleveland, $\mathrm{OH}$ ), and consensus sequences were determined using MacVector (Kodak, Rochester, NY).

For the isolation of additional splice variants by RT-PCR, total RNA was extracted from E13 brain using the RNAzolB method (Tel-Test, Friendswood, TX). Reaction conditions for the reverse transcription and PCR amplification were as described in the GeneAmp RNA PCR kit (Perkin Elmer Cetus, Norwalk, CT). TK + products were amplified with the $\mathrm{PCR}+/ \mathrm{FL}$ - primer pair, and $\mathrm{KD}$ products were amplified with the $\mathrm{PCR}+/ \mathrm{KD}$ - primer pair (see Fig. 6). RNA $(1 \mu \mathrm{g})$ was reversetranscribed and PCR amplified for 35 cycles using an annealing temperature of $50^{\circ} \mathrm{C}$ (Saiki et al., 1988). To improve resolution of the multiple products of the TK+ PCR amplification, the reaction was digested overnight at $37^{\circ} \mathrm{C}$ with either Bam HI or Rsa 1 restriction enzyme (Boehringer Mannheim, Indianapolis, IN). Unless otherwise noted, the products were separated on a $1.5 \%$ agarose gel, $\mathrm{NaOH}$ denatured, and transferred to Genescreen Plus (NEN/DuPont, Wilmington, DE) as described previously (Chomczynski, 1992). Southern blots were incubated overnight in HYB buffer containing $50 \%$ formamide at $58^{\circ} \mathrm{C}$ with one of two ${ }^{32} \mathrm{P}$-labeled riboprobes. The TK probe for TK + PCR products was complementary to nucleotides 1593-1910, corresponding to the juxtamembrane (JM) domain and a portion of the kinase domain. The EC probe for KD PCR products was complementary to nucleotides 1119 1293, corresponding to a portion of the EC domain upstream of the unique Bam $\mathrm{H} 1$ site (see Fig. 6). Final washes were done at $63^{\circ} \mathrm{C}$ in $0.1 \times$ SSPE and $0.1 \%$ SDS $\left(10^{\circ} \mathrm{C}\right.$ below $\left.\mathrm{Tm}\right)$, and the blots were placed either under $\mathrm{x}$-ray film or quantified by phosphorimage analysis (Molecular Dynamics, Sunnyvale, CA). In some cases, blots also were stripped and hybridized with ${ }^{32} \mathrm{P}$-labeled oligo probes corresponding to the $\mathrm{J} 1$ and $\mathrm{J} 2$ insertions (see Fig. $7 A, B$ ). For sequencing of the RT-PCR products, individual bands were eluted from the gel and reamplified for 25 cycles, and the products were subcloned into the pCRII TA vector (Invitrogen, San Diego, CA)

In situ hybridization. Embryos at age $\mathrm{E} 6$ were fixed by immersion in $4 \%$ $p$-formaldehyde at $4^{\circ} \mathrm{C}$, and embryos at E10 and older were fixed by transcardial perfusion with PBS followed by $4 \% p$-formaldehyde at $4^{\circ} \mathrm{C}$ The brain and eyes were removed and immersed in fixative for $4 \mathrm{hr}$, followed by PBS containing $30 \%$ sucrose at $4^{\circ} \mathrm{C}$ for overnight. After this cryoprotection step, $20 \mu \mathrm{m}$ frozen sections were mounted on Superplus slides (Fisher, Pittsburgh, PA) and air-dried for 2-3 hr before in situ hybridization using a modification of the method described by SchaerenWiemers and Gerfin-Moser, 1993. Digoxigenin-labeled antisense and sense (control) riboprobes corresponding to the EC domain of the TrkB receptor were transcribed from a linearized template containing a $1.2 \mathrm{~kb}$ insert. To facilitate tissue penetration, the probes were reduced to $\sim 300$ bases in length by alkaline hydrolysis at $65^{\circ} \mathrm{C}$ for $10 \mathrm{~min}$. Sections were prehybridized overnight at room temperalure in $5 \times \mathrm{SSC}, 50 \%$ formamide, $5 \times$ Denhardt's solution, $250 \mu \mathrm{g} / \mathrm{ml}$ tRNA, and $50 \mu \mathrm{g} / \mathrm{ml}$ sheared herring sperm DNA. Sections then were hybridized with probe for $16 \mathrm{hr}$ at $65^{\circ} \mathrm{C}$ under sealed coverslips and washed in $0.2 \times \mathrm{SSC}$ for $1 \mathrm{hr}$ at $65^{\circ} \mathrm{C}$. Endogenous alkaline phosphatase was inhibited by $0.24 \mathrm{mg} / \mathrm{ml}$, levamisol, and the digoxigenin-labeled probes were detected with the Genius kit (Boehringer Mannheim, Indianapolis, IN) according to the manufacturer's instructions. For comparison of antisense and sense probe hybridizations, slides of neighboring sections were processed together to eliminate any variation in immunostaining, enzymatic reactions, or detection.

$R T$-PCR analysis of TrkB mRNA expression. To perform semiquantitative RT-PCR analysis, the exponential phasc for PCR amplification of TrkB isoforms was determined empirically by a cycle dilution experiment using E13 brain total RNA and the PCR +/FL - primer pair. The amount of each isoform produced between cycles 20 and 32 was quantified by phosphorimaging of Southern blots. A plot of $\{\log$ of product $\}$ versus \{cycle number demonstrated that the efficiency of amplification (see Golde et al., 1990) of each isoform was essentially identical (0.80) and that the rate of production was linear through 30 cycles (data not shown).

For RT-PCR analysis of receptor isoform expression, total RNA was extracted from the retina and optic tectum of embryos between ages E5 to E19 and 6-week-old hatched chickens (adult). After reverse transcription of $1 \mu \mathrm{g}$ of total RN $\Lambda$ and 30 cycles of amplification with either the $\mathrm{PCR}+/ \mathrm{FL}-$ or $\mathrm{PCR}+/ \mathrm{KD}-$ primer pairs, the products were electrophoresed and Southern-blotted as described above. Blots first were probed with a ${ }^{32} \mathrm{P}$ end-labeled oligonucleotide complementary to the J1 motif overnight at $50^{\circ} \mathrm{C}$ in $\mathrm{HYB}$ buffer and washed in $2 \times$ SSPE and $0.1 \%$ SDS at $52^{\circ} \mathrm{C}\left(10^{\circ} \mathrm{C}\right.$ below $\left.\mathrm{Tm}\right)$. The blots then were stripped and reprobed with a ${ }^{32} \mathrm{P}$ end-labeled oligonucleotide complementary to the $\mathrm{J} 2$ motif. Finally, the blots were stripped and hybridized with the appropriate TK or EC riboprobe. The blots were analyzed on a phosphorimager (Molecular Dynamics, Sunnyvale, CA) and the TIFF images adjusted for contrast using the NIH Image 1.54 program. For the preparation of Figures 9 and 10, the images then were combined using Aldus Photoshop, lettered in Microsoft Superpaint 3.5, and printed on a Tektronics Color Phaser 440.

For analysis of the developmental expression of receptor isoforms, the band densities on the Southern blots were quantified using a phosphorimager. The equivalent amplification efficiencies for isoforms sharing common forward and reverse primer sites, e.g., TK+ isoforms, allowed their relative proportion within each sample to be determined unambiguously. For comparison of isoform expression between samples, two controls were used. First, the integrity of the template RNA and the accuracy of the RNA concentrations of each sample were checked by electrophoresis of the total RNA samples on an ethidium/bromide formaldehyde agarose gel. Second, $\beta$-actin was amplified under identical RT-PCR conditions and used as a control to normalize the amount of TrkB isoforms produced (Horikoshi et al., 1992).

\section{RESULTS}

\section{TrkB receptor mRNA expression in the developing chick visual system}

TrkB transcripts were localized in the developing avian visual system by in situ hybridization with a digoxigenin-labeled riboprobe against the EC domain that recognizes all known TrkB splice variants (Table 1). Within the E6 retina (Fig. 1A,B), the antisense riboprobe labeled cells of the forming RGC layer, but not the proliferating cells of the ventricular zone (VC) or the retinal pigment epithelium. The staining of individual presumptive RGCs was limited to the central regions of the retina, in which the first RGCs begin to differentiate and establish axonal contact with the tectum (Rager, 1980; Thanos and Bonhoeffer, 1983). By E10, when nearly all RGCs have been produced (Kahn, 1973) and just before the period of cell death (Hughes and 
Table 1. Summary of TrkB mRNA expression in the visual system of the developing chick embryo

Relative expression of TrkB

\begin{tabular}{|c|c|c|c|c|c|c|}
\hline \multirow[b]{2}{*}{ Region } & \multirow[b]{2}{*}{ Layer } & \multirow[b]{2}{*}{ Afferents } & \multirow[b]{2}{*}{ Efferents } & \\
\hline & & & & E6 & E10 & $\mathrm{E} 21$ \\
\hline \multicolumn{7}{|l|}{ Eye } \\
\hline \multirow[t]{3}{*}{ Retina } & $\mathrm{RGC}$ & INL & Tectum, Thalamus & $+++^{a}$ & ++++ & ++++ \\
\hline & $\mathrm{INL}^{c}$ & PR and ION & $\mathrm{RGC}$ & - & + & ++ \\
\hline & FR & Light & INL & - & + & ++ \\
\hline \multicolumn{7}{|l|}{ Mesencephalon } \\
\hline Optic & SGF & $\begin{array}{l}\text { RGC (a-f) and } \mathrm{SpL} \\
\quad(\mathrm{g}-\mathrm{j})\end{array}$ & $\mathrm{SGC}$ & + & $++++^{b}$ & ++++ \\
\hline Tectum & SGC & $\mathrm{RGC}$ and $\mathrm{SpL}$ & $\begin{array}{l}\text { ION, NI, PRF, ROT, } \\
\text { LGV }\end{array}$ & + & ++++ & +++++ \\
\hline Nucleus Isthmi (NI) & $\begin{array}{l}\text { IMC } \\
\text { IPC }\end{array}$ & $\begin{array}{l}\text { Both receive SGC and } \\
\text { other sensory inputs }\end{array}$ & $\begin{array}{l}\text { Both project back } \\
\text { onto the tectum }\end{array}$ & - & $\begin{array}{l}++++ \\
++++\end{array}$ & $\begin{array}{l}+++++ \\
+++++\end{array}$ \\
\hline Isthmo-optic (ION) & Nucleus & SGF & INL & - & +++ & +++++ \\
\hline Ectomammillary (EM) & Nucleus & $\mathrm{RGC}$ & OMC, Cerebellum & + & $+t$ & +++ \\
\hline Lateral Spiriform (SpL) & Nucleus & Basal ganglia and telen. & SGF $(g-j)$ and SGC & - & ++++ & +++++ \\
\hline \multicolumn{7}{|l|}{ Diencephalon } \\
\hline Lateroventral & Internal (LGvil) & RGC and SGC & Tectum, thalamus, telen. & - & +++ & +++++ \\
\hline Geniculate nucleus & External (LGvexl) & RGC and SGC & Tectum, thalamus, telen. & - & - & - \\
\hline $\begin{array}{l}\text { Lateroventral geniculate } \\
\text { intercalated (LGi) }\end{array}$ & Nucleus & RGC & Tectum, thalamus, telen. & - & - & - \\
\hline $\begin{array}{l}\text { Dorsal lateral geniculate } \\
\text { superficial magnocellular } \\
\text { (SM) }\end{array}$ & Nucleus & $\mathrm{RGC}$ & Tectum, thalamus, telen. & - & +++ & +++++ \\
\hline \multicolumn{7}{|l|}{$\begin{array}{l}\text { Dorsal lateral geniculate } \\
\text { superficial synencephalic }\end{array}$} \\
\hline (SS) & Nucleus & $\mathrm{RGC}$ & Tectum, thalamus, telen. & - & - & - \\
\hline \multicolumn{7}{|c|}{ Dorsolateral anterior thalamus } \\
\hline lateral division (DLL) & Nucleus & RGC & Tectum and telen. & - & - & - \\
\hline $\begin{array}{c}\text { Dorsolateral anterior thala } \\
\text { anterior division (DLA) }\end{array}$ & Nucleus & RGC & Tectum and telen. & - & - & - \\
\hline $\begin{array}{l}\text { Lateral anterior thalamus } \\
\text { (LA) }\end{array}$ & Nucleus & RGC & Tectum and telen. & - & - & ++ \\
\hline Nucleus rotundus (ROT) & Nucleus & SGC & Cortical structures & - & ++ & ++++ \\
\hline $\begin{array}{l}\text { Lateral hypothalamic/supra } \\
\text { chiasmatic (SCN) }\end{array}$ & Nucleus & RGC & Hypothalamic nuclei & - & ++ & ++ \\
\hline
\end{tabular}

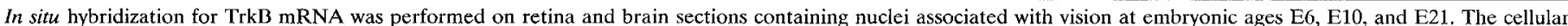

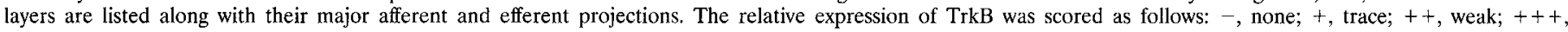
intermediate; ++++ , strong; +++++ , intense.

${ }^{a}$ At E6, only RGCs in the central retina are labeled.

${ }^{b}$ At E10, the deeper layers of the forming SGF are labeled.

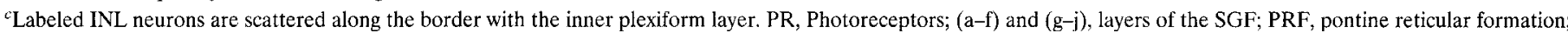
OMC, oculomotor complex; Telen., telencephalon.

\footnotetext{
Figure 1. Figures 1-4, show in situ localization of TrkB rcccptor transcripts in the embryonic avian visual system. Sections were hybridized with a digoxigenin-labeled riboprobe corresponding to the $\mathrm{EC}$ domain of the TrkB receptor, which is contained in all known TrkB transcripts. TrkB mRNA expression in the E6 retina. $A$, The blue reaction product is found in cells (white arrows) that have migrated to the $R G C$ layer at the vitreal surface. No labeling is observed in the proliferating cells of the ventricular zone $(V Z)$ or within the brown, melanin-bearing retinal pigment epithelium $(R P E)$. Scale bar, $40 \mu \mathrm{m}$. $B$, Higher magnification of the RGC layer demonstrating intense cytoplasmic labeling of a presumptive RGC. Scale bar, $10 \mu \mathrm{m}$.

Figure 2. TrkB mRNA expression in the $\mathrm{E} 21$ retina. $A, B$, Low magnification of the retina hybridized with either the antisense probe $(A)$ or the sense control probe $(B)$. The layers of the retina are indicated at the left, with the exception of the outer plexiform layer between the $O N L$ and $I N L$, which becomes more prominent after hatching. Scale bar, $33 \mu \mathrm{m}$. $C, D$, Higher magnification of the $I N L$, IPL, and $R G C$ layers hybridized with the sense control probe $(C)$ or the antisense probe $(D)$. TrkB $m R N A$ is expressed in large cells in the $R G C$ layer (arrows) and scattered cells (arrowhead) in the inner nuclear layer $(I N L)$ along the border with the inner plexiform layer $(I P L)$. Scale bar, $40 \mu \mathrm{m}$. $E$, Higher magnification of the $R G C$ layer demonstrates labeling in the cytoplasm of many large cells. Scale bar, $15 \mu \mathrm{m} . F, G$, Higher magnification of the $O N L$ layer hybridized with either the sense control probe $(F)$ or the antisense probe $(G)$ showing labeling of the cytoplasm around nuclei in the ONL. The labeling of the photoreceptor cells was weak compared with the strong labeling of the RGCs. Scale bar, $8 \mu \mathrm{m}$.
} 


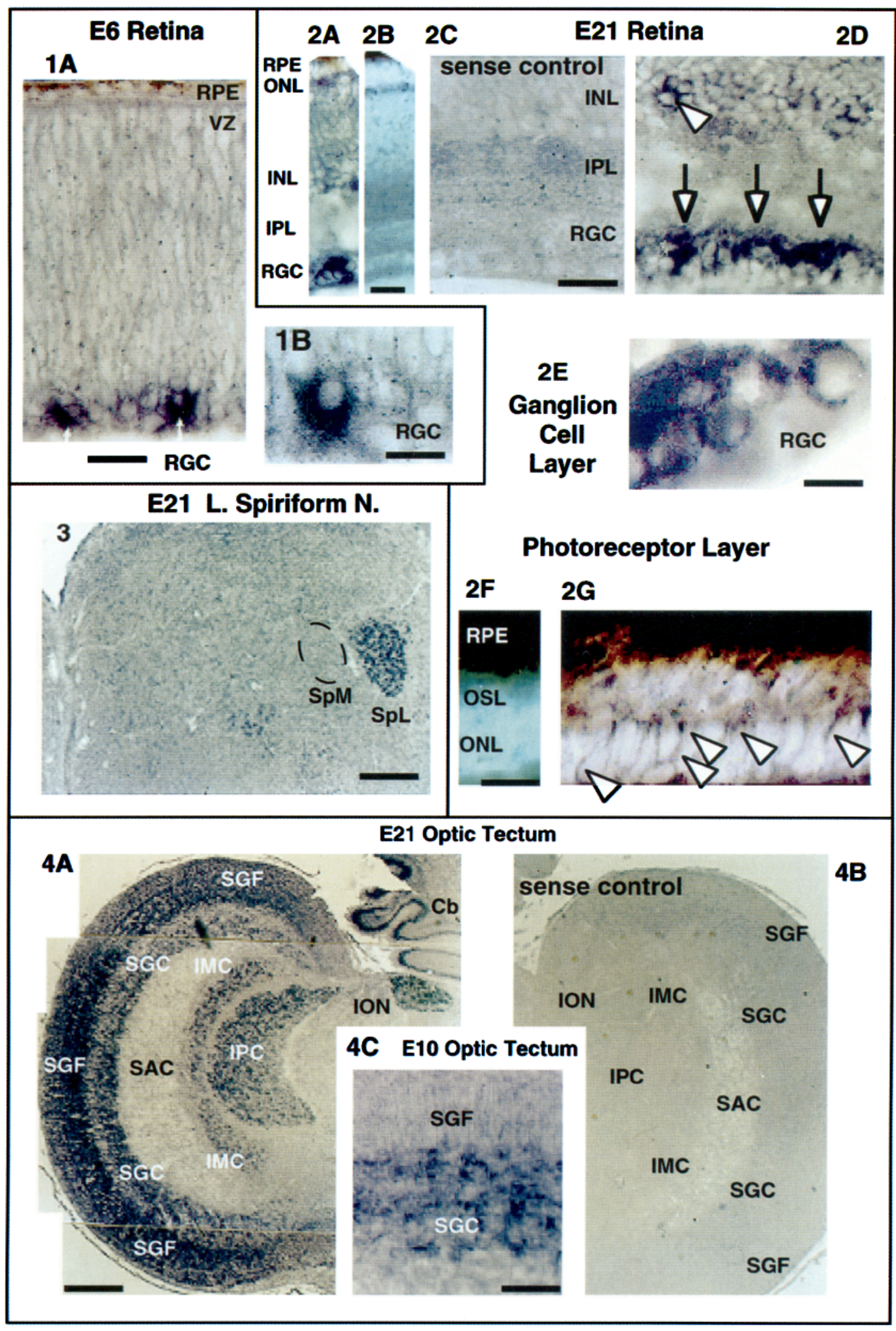

Figure 3. TrkB mRNA expression in the E21 SpL. The $S p L$, which innervates the tectum, is labeled intensely, but not the neighboring medial spiriform nucleus $(S p M)$, which is not involved in the visual system and forms a descending projection. Scale bar, $600 \mu \mathrm{m}$.

Figure 4. TrkB mRNA expression in the optic tectum and midbrain. A, At E21, the trkB antisense riboprobe intensely labeled the $S G F$ and the $S G C$, the two neuronal layers of the optic tectum innervated by RGCs. Note the absence of staining in the underlying plexiform layer [stratum album centrale $(S A C)$ ]. The nucleus isthmi (IMC and $I P C)$, which receives input from the $S G C$, was labeled, as was the ION, which receives input from the $S G C$ and innervates the retina. Large cells within the Purkinje cell layer of the cerebellum $(C b)$ also were labeled. $B$, Section hybridized with the control sense riboprobe. $C$, At E10, the $S G C$ and only the deeper layers of the $S G F$ were labeled. Scale bars: $A, B, 800 \mu \mathrm{m} ; C, 100 \mu \mathrm{m}$. 


\section{TECTO-FUGAL THALAMO-FUGAL TrkB mRNA}
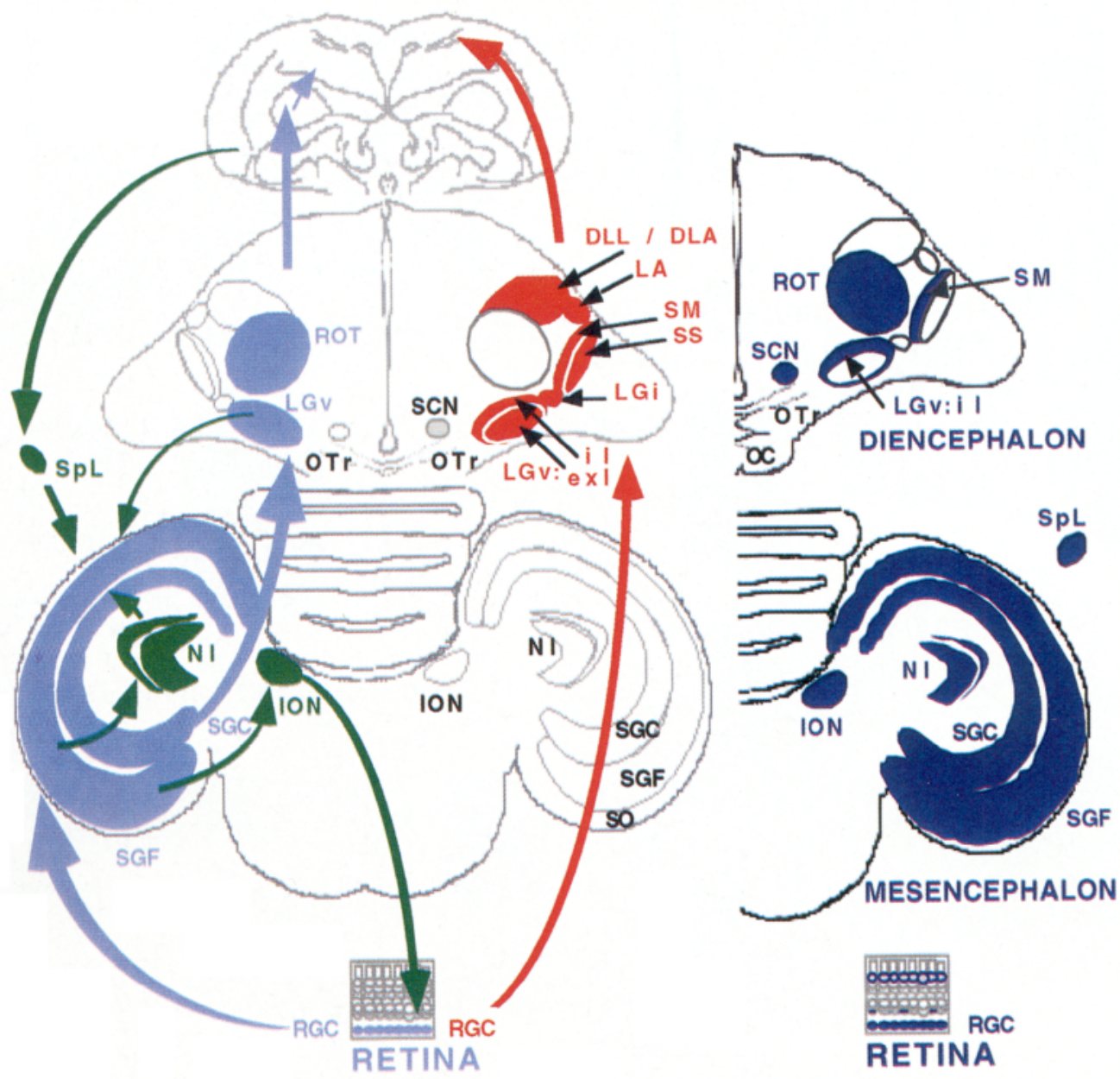

Figure 5. Schematic representation of the functional relationships between the regions of the avian visual system and TrkB mRNA expression at E21. The principal visual nuclei of the mesencephalon and diencephalon are included in each panel, and the two paths taken by visual information en route to the cortex are indicated by arrows. The major tectofugal pathway (light blue) includes regions of the avian tectum that receive direct retinal input and the two major diencephalic nuclei that receive second-order visual inputs from the tectum. The minor thalamofugal pathway that receives direct retinal input is shaded in red. Nuclei that innervate the tectum and retina are potential feedback loops and are shaded in green. TrkB mRNA expression is shaded in purple. $R G C$, Retinal ganglion cells; $S G F$, stratum griseum et fibrosum superficiale; $S G C$, stratum griseum centrale; $M I$, nucleus isthmus; $I O N$, isthmo-optic nucleus; $S p L$, lateral spiriform nucleus; $O C$, optic chiasm; $O T r$, optic tract; $S C N$, lateral hypothalamic/suprachiasmatic nucleus; $L G v: i l$ and $L G v$ :exl, internal and external layers respectively, of the LGv; $L G i$, intercalated layers of the lateroventral geniculate nucleus; $S S$, dorsal lateral geniculate, superficial synencephalic; $S M$, dorsal lateral geniculate, superficial magnocellular; $L A$, lateral anterior thalamus; $D L L$, dorsolateral anterior thalamus, lateral division; $D L A$, dorsolateral anterior thalamus, anterior division; and $R O T$, nucleus rotundus.

McLoon, 1979), labeling had extended to cells in the peripheral RGC layer. At E21, after the period of cell death and midway through the period of synaptogenesis in the inner plexiform layer (Large et al., 1985), many cells within the RGC layer were labeled intensely (Fig. 2A,D). The predominant class of RGC that expressed TrkB mRNA appeared to have a relatively large cell body (Fig. $2 E$ ). The photoreceptor layer also was labeled weakly (Fig. $2 A, G)$, as were scattered cells [likely to be either amacrine or displaced ganglion cells (Fig. $2 D$ )] along the inner margin of the inner nuclear layer.

TrkB mRNA expression was surprisingly strong in the stratum griseum et fibrosum superficiale (SGF) and the stratum griseum centrale (SGC) (see Fig. 4A), the neuronal layers of the optic tectum that receive RGC innervation via their dendrites in the superficial layers of the SGF (Mey and Thanos, 1992). The first RGC axons reach the anterior ventral pole of the contralateral tectum by E6, extend across the superficial stratum opticum (SO) ovcr the next week, and ramify within deeper tectal layers to form topographic and laminar-specific connections beginning at E12 (LaVail and Cowan, 1971; Rager and von Oeynhausen, 1979; Thanos and Bonhoeffer, 1987). TrkB mRNA expression was present in the SGF and SGC as early as E6 (Table 1) and had increased by E10, with the SGC and the deeper layers of the SGF labeled more strongly (see Fig. $4 C$ ). By E21, labeling was relatively intense in both the SGC and the superficial and deep layers of the SGF (see Fig. 4A), although not all cells were TrkB mRNA-positive. Labeling appeared to be predominantly neuronal, because plexiform layers were unlabeled and the large size of the labeled cells in the SGC are typical of neurons in this layer (data not shown).

TrkB mRNA also was detected in several other regions involved in processing visual information (Table 1). The ION, which receives tectal efferents and innervates amacrine cells within the retina, is dependent on the retina for trophic support during the 


\section{TK+ Receptor Isoforms}

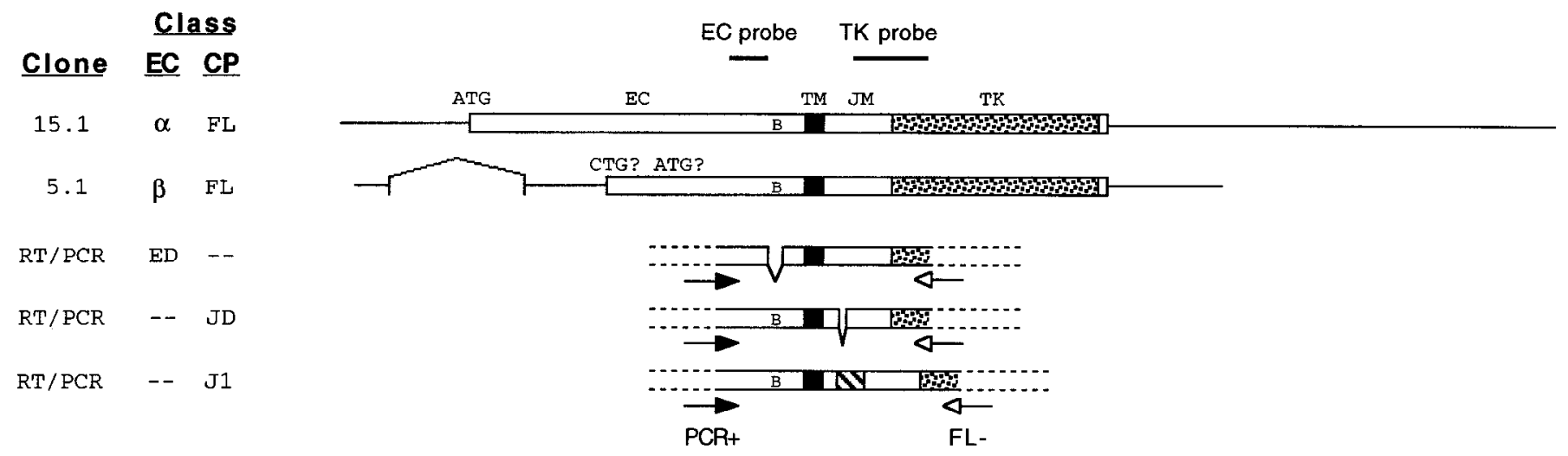

KD Receptor Isoforms

$\begin{array}{ccl}17.1 & \alpha & \mathrm{T} 1 \\ \mathrm{RT} / \mathrm{PCR} & -- & \mathrm{J} 1+\mathrm{T} 1 \\ \mathrm{RT} / \mathrm{PCR} & -- & \mathrm{J} 2+\mathrm{T} 1 \\ \mathrm{RT} / \mathrm{PCR} & \mathrm{ED} & \mathrm{J} 2+\mathrm{T} 1 \\ \mathrm{RT} / \mathrm{PCR} & -- & \mathrm{J} 1+\mathrm{J} 2+\mathrm{T} 1 \\ \mathrm{RT} / \mathrm{PCR} & -- & \mathrm{T} 3 \\ \mathrm{RT} / \mathrm{PCR} & \mathrm{ED} & \mathrm{J} 1+\mathrm{J} 2+\mathrm{T} 1\end{array}$
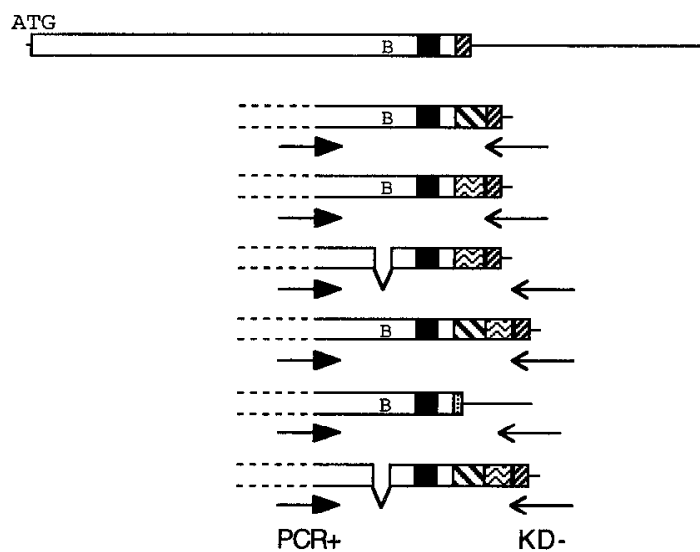

Kilobases

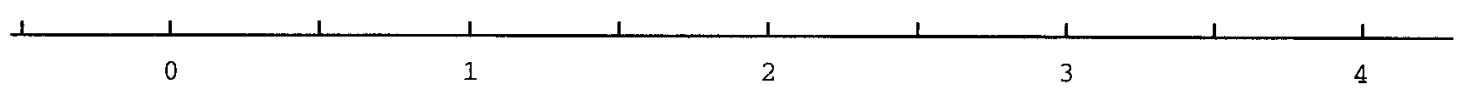

Figure 6. Schematic representations of the avian TrkB receptor isoforms. Translation start codons (ATG) and the extracellular BamHI restriction site $(B)$ are indicated along with the $E C, T M, J M$, and $T K$ domains. The EC and TK probes used to probe RT-PCR products are indicated by black bars. The isoforms are separated into $T K+$ and $K D$ receptor classes and are classified according to the unique motifs seen in the $E C$ and cytoplasmic $(C P)$ domains. Clones were isolated either from an E13 chick brain cDNA library (clones 15.1, 5.1, and 17.1) or from E13 chick brain total RNA by RT-PCR. Amplification used an upstream $P C R+$ primer (black arrow) and either the $F L$ - primer to the kinase domain (white arrow) or the KD-primer to the $\mathrm{T} 1$ motif (line arrow). All schematized isoforms were characterized by sequencing and, in the case of isoforms containing the J1 and/or J2 isoforms, by Southern blotting of RT-PCR products. Three extracellular motifs were identified: the $\alpha \mathrm{N}$ terminus of the FL receptor, the $\beta \mathrm{N}$-terminal truncation, and the ED that eliminates the Bam $\mathrm{H} 1$ site. The cytoplasmic motifs consisted of the JM and kinase domains of the $\Gamma L$ receptor, a JD, two JM insertions (J1 and $\mathrm{J} 2$ ), and two KD motifs (T1 and T3). The CTG? and $A T G$ ? indicate the location of possible alternative, in-frame translational start sites for the $\beta$ $\mathrm{N}$-terminal motif. The scale bar at bottom indicates the sizes of the cDNA clones and PCR products.

period of cell death between E13 and E17 (Clarke, 1992). TrkB labeling appeared as early as E10, and virtually all cells within the ION expressed TrkB mRNA by E21 (see Fig. $4 A$ ). The two neuronal layers of the nucleus isthmi (Fig. $4 A$ ), the isthmus pars magnocellularis (IMC), and isthmus pars parvocellularis (IPC), as wcll as the lateral geniculate nucleus (Table 1), receive tectal efferents (Hunt and Kunzle, 1976) and were labeled by the antisense TrkB riboprobe. The lateral spiriform nucleus (SpL), which innervates the tectum (Reiner et al., 1982), also expressed TrkB mRNA (Fig. 3). Figure 5 is a schematic relating the widespread TrkB mRNA expression (right panel, dark blue shading) to the major pathways for processing of visual information in the avian CNS (left panel). The principal visual nuclei of the mesencephalon and diencephalon are included in each panel, and the two paths taken by visual information en route to the cortex are indicated by arrows (Ehrlich and Mark, 1984). Most of the nuclei in the major tectofugal pathway (light blue) express TrkB mRNA, including the two neuronal layers of the tectum that receive direct retinal input and the two major diencephalic nuclei that receive second-order inputs from the tectum. In addition, nuclei that innervate the tectum and retina and are potential feedback loops (green) express TrkB mRNA. Some of the diencephalic nuclei in the minor thalamofugal pathway that receive direct retinal input $(r e d)$ also express TrkB mRNA.

\section{Characterization of TrkB receptor isoforms}

Although in situ localization with the EC domain probe served to identify the complete range of TrkB mRNA expression in the 

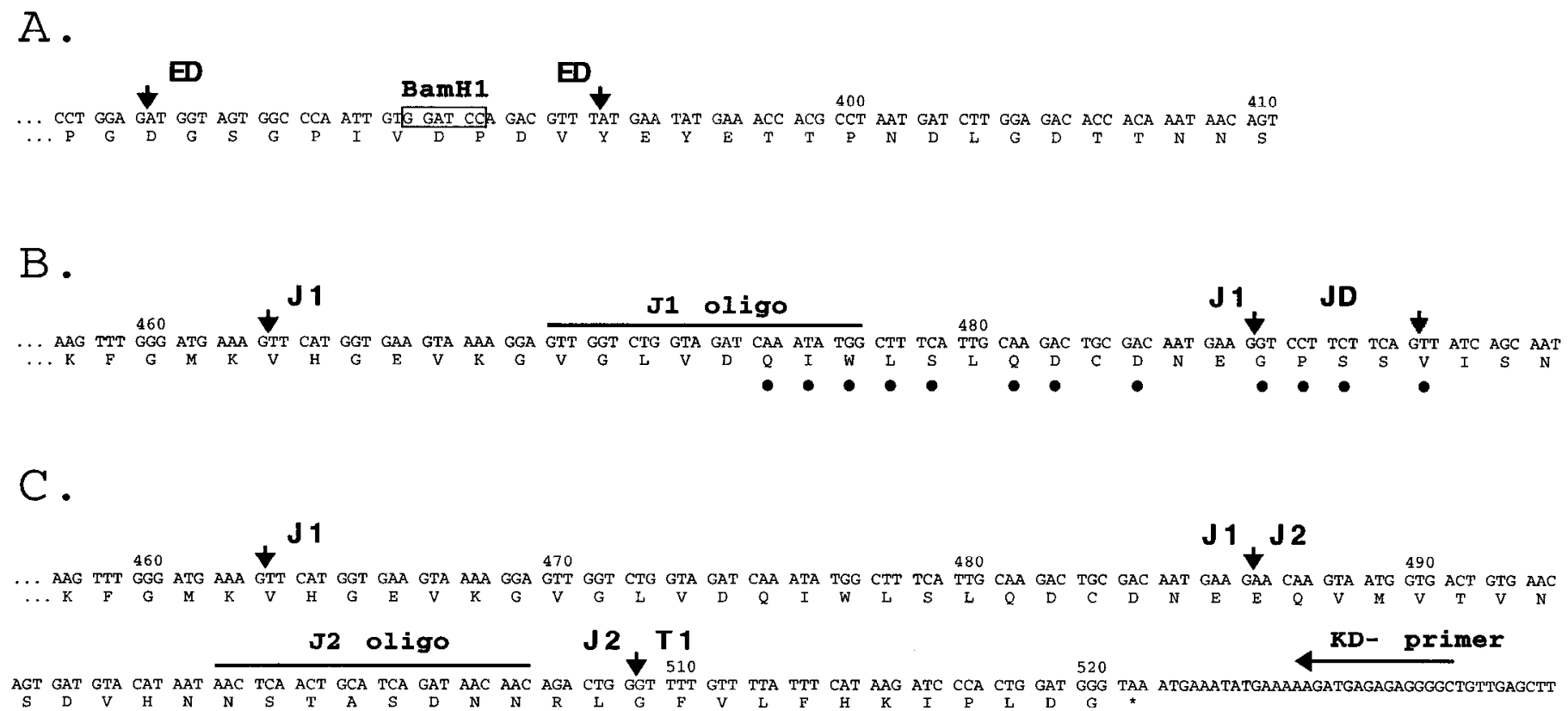

D.

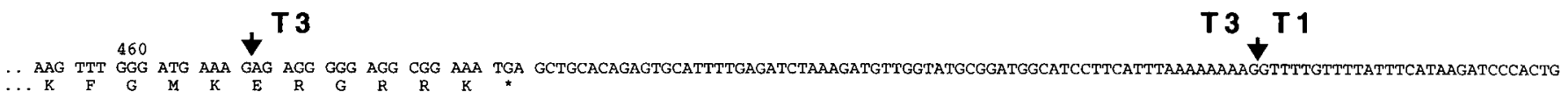

GATGGGTAAATGAAATATGAAAAAGATGAGAGAGGGGTGTTGAGCTTGTTATGGAAGCTGTATGCTGCACACTAGGGAGTGGACAGTGTTCTTGCCC

Figure 7. Nucleic acid and deduced amino acid sequences of the avian TrkB isoforms. $A$, ED isoform. The $E D$ motif is missing nucleotide sequence in the EC domain, flanked hy arrows, that contains the unique Bam H1 site. $R, \mathrm{~J} 1$ and JD isoforms of TK+ receptors. Arrows mark the J1 insertion and the sequence that is missing in the $J D$ motif. Clones were isolated that contained either the $J 1$ or the $J D$ motif, although Southern blots of RT-PCR products indicated that some transcripts may contain both motifs (data not shown). The location of the $J 1$ oligo probe is indicated by the thick line. The residues that are conserved with the $\mathrm{C}$-terminal domain of $\beta$-actin are indicated by black dots. $C, \mathrm{~J} 1$ and $\mathrm{J} 2$ isoforms of $\mathrm{KD}$ receptors. As schematized in Figure 6 , the T1 motif may occur independently, with one or both of the JM insertion ( $J 1$ and $J 2$ ) motifs. Five residues of the JM domain are shown, followed by the inserted nucleotide sequences, flanked by large arrows. The horizontal arrow indicates the position and length of the KD- primer used for the RT-PCR amplification of the $\mathrm{KD}$ isoforms. The location of the $J 2$ oligo probe is indicated by the black bar. $D$, T3 isoform of the KD receptor. The $T 3$ insert, flanked by large arrows, is followed by the $T 1$ sequence. The T3 sequence contains a stop codon, resulting in a KD isoform with a predicted novel C terminus.

visual system, it could not discriminate between receptor isoforms. Members of the Trk gene family are alternatively spliced within both the EC and cytoplasmic domains to yield receptor variants with potentially diverse functions (Klein et al., 1990; Middlemas et al., 1991; Meakin et al., 1992; Lamballe et al., 1993; Tsoulfas et al., 1993; Valenzuela et al., 1993; Garner and Large, 1994). To begin to characterize avian TrkB isoforms, an E13 chick brain cDNA library was screened and three classes of cDNAs were isolated; a full length (FL) receptor (clone 15.1), which is essentially identical to a cDNA reported previously (Dechant et al., 1993), an $\mathrm{N}$-terminal truncated isoform (clone 5.1) and a KD isoform (clone 17.1) (Fig. 6). The cDNA coding for the $\mathrm{KD}$ isoform replaces nearly all of the cytoplasmic domain with 11 amino acids that are conserved completely in the mouse and rat homologs, called the T1 isoform (Klein et al., 1990; Middlemas et al., 1991). Compared with the nucleotide sequence coding for the $\mathrm{N}$ terminus of the FL receptor, called the $\alpha$ motif, the $\beta$ motif of the $\mathrm{N}$ terminal truncation deletes 555 nucleotides and fuses part of the $5^{\prime}$ untranslated sequence with the coding sequence beginning at nucleotide 210 (Fig. 6). This seems to result from the splicing out of the exon(s) coding for the start codon, the signal peptide, and the first cysteine cluster of the $\alpha$ motif. Inspection of the $\beta$ sequence reveals that codons 144 (Leu) and 188 (Met) are in an appropriate context to initiate translation of the remainder of the receptor, including the tyrosine kinase (TK) domain. The TrkB $\beta$ extracellular motif is very similar in structure to a $\mathrm{N}$-terminal variant of chicken TrkC identified previously (Garner and Large, 1994) and may be a common feature of the Trk receptor family, because $\mathrm{N}$-terminal variants also have been identified by Northern analysis in mammals (Klein et al., 1990; Middlemas et al., 1991).

EC deletion (ED) variants of mammalian Trk receptors lack short sequences between the second Ig-like domain and the TM domain (Meakin et al., 1992; Shelton et al., 1995) and, in the case of TrkA, this motif alters ligand-binding properties (Clary and Reichardt, 1994). To determine whether similar variants of TrkB exist, E13 brain RNA was subjected to RT-PCR amplification of the coding region between the last EC cysteine (Fig. 6, PCR+ primer) and the first 30 residues of the tyrosine kinase domain ( $F L$ - primer). Southern blotting with the TK probe (see Fig. 8, lane 1) identified one prominent band, which comigrated with the 714 bp product amplified from the FL cDNA clone (lane 6), and two minor bands. Although most RT-PCR products from the 


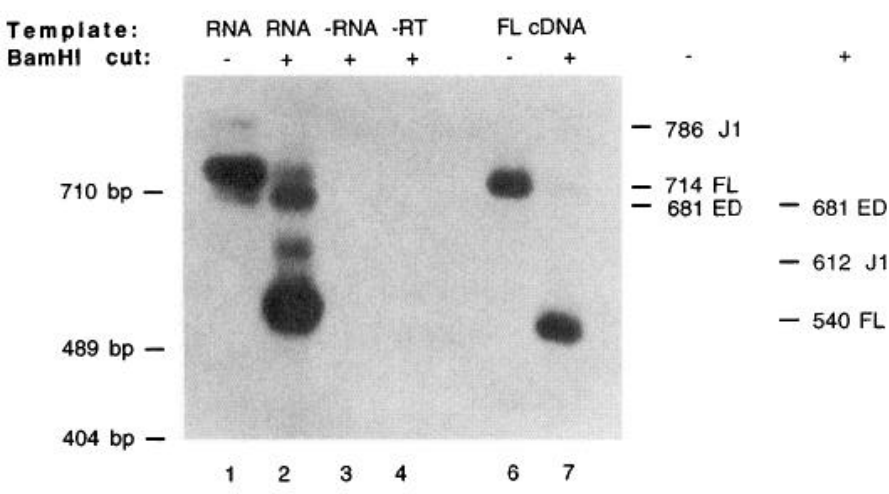

Figure 8. RT-PCR amplification of TK+ receptor isoforms from E13 chick brain RNA. The $E D$ and $J 1$ insertion motifs are contained within transcripts that also contain the TK domain. Brain total RNA was reversetranscribed and PCR-amplified with the PCR+ and FL- primers. The products, either uncut (lanes 1, 6) or digested with BamHI (lanes 2, 3, 4, 7), were analyzed by Southern blot with the 32-P labeled TK probe. Lanes 1, 2, RT-PCR of $1 \mu \mathrm{g}$ of E13 brain total RNA; lane 3, no RNA template control reaction; lane 4, no reverse transcriptase control reaction; lanes 6, 7 , PCR positive control amplification of the $F L c D N A$ clone. The sizes of the expected products, for both digested and uncut reactions, are indicated on the right, and the molecular weight markers are indicated on the left. Bam $\mathrm{H} 1$ digestion shifts the major 714 bp FL band (lanes 1, 6) to 540 bp (lanes 2, 7). The residual signal at $714 \mathrm{bp}$ after digestion, which was $<5 \%$ of the uncut band, may be attributable to incomplete digestion or PCR mutation of the Bam H1 site in a minority of the products. The band at 786 bp corresponding to the $J 1$ insert is reduced by a similar amount by $B a m \mathrm{H} 1$ digestion, but the band at 681 bp corresponding to the $E D$ motif is unchanged by digestion (lanes 1,2 ).

major band were identical to the FL sequence, a small portion was missing 12 nucleotides at the splice site used by the T1 isoforms called the JD isoform (Figs. 6, 7B). Sequencing of the minor 681 bp band demonstrated that 33 nucleotides containing the EC Bam HI site were missing (Figs. 6, 7A), thereby identifying an avian TrkB ED isoform. The amplification of the ED isoform from brain RNA was confirmed by its resistance to Bam $\mathrm{H} 1$ digestion (Fig. 8, lane 2). Finally, the 786 bp band (Fig. 8, lane 1) was reduced to 612 bp (lane 2) by Bam HI digestion, indicating that this PCR product contained additional sequence downstream of the Bam HI site. Sequence analysis revealed that 72 nucleotides $(\mathrm{JI})$ were inserted in the JM domain (Figs. 6, 7B). A search of Genbank revealed that the $\mathrm{J} 1$ insert displayed strongest homology to the $\mathrm{C}$ terminus of $\beta$-actin, a region important for binding regulatory proteins such as profilin (Pollard et al., 1994).

Another major class of Trk receptor splice variants are the KD isoforms, which lack the tyrosine kinase domain (Barbacid, 1994). Additional TrkB isoforms that contain the T1 motif were identified by RT-PCR using the KD- downstream primer (Fig. 6) and the PCR+ upstream primer. A range of products hybridized on Southern blots with the EC probe to the EC domain (Fig. 9, lane 1 ). The smallest band at $\sim 450$ bp comigrated with the product from the T1 cDNA clone (lane 8 ) and by sequencing was found to be identical. An oligonucleotide complementary to the $\mathrm{J} 1$ insert hybridized weakly to the broad band centered at $525 \mathrm{bp}$ and more strongly to the diffuse band at $\sim 600 \mathrm{bp}$. Sequence analysis revealed that the $600 \mathrm{bp}$ band contained receptor isoforms with a novel insertion (J2) of $69 \mathrm{bp}$ immediately downstream of J1 (Fig. 9, lane 4; Fig. $7 B$ ) and, in some clones, the $\mathrm{J} 1+\mathrm{J} 2$ isoform also contained the ED motif (Fig. 6). Probing the RT-PCR products with an oligonucleotide to the $\mathrm{J} 2$ insert labeled the band at $600 \mathrm{bp}$ (Fig. 9, lane 3) and, more strongly, the broad band at 525 bp.
Sequence analysis of clones isolated from this broad band confirmed that either the $\mathbf{J} 1$ or $\mathbf{J} 2$ sequence motif occurred singly with the $\mathrm{T} 1$ motif (Fig. 9, lanes 6, 7), but that the $\mathrm{J} 2$ motif was more common (15/18 clones). One clone contained the $\mathrm{J} 2$ insert with the ED motif (ED/J2); although no ED/J1 clones were identified, this may be attributable to the lower abundance of the $\mathrm{J} 1$ motif relative to the $\mathrm{J} 2$ motif. Finally, sequence analysis of a single clone (Fig. 9, lane 5) from the broad band at 525 bp demonstrated that a third sequence of 89 nucleotides also can be inserted upstream of the T1 motif (Fig. 7D) and codes for a novel $\mathrm{C}$ terminus of six amino acids. This isoform is called T3, in keeping with the nomenclature for the mammalian $\mathrm{KD}$ isoforms (Middlemas et al., 1991).

\section{Developmental expression of TrkB transcripts in the retina}

The identification of alternatively spliced TrkB receptors raised the possibility that development- or region-specific expression of receptor isoforms underlie the widespread distribution of TrkB transcripts in the visual system. To characterize the expression of individual TrkB isoforms, semiquantitative RT-PCR (Horikoshi et al., 1992) was performed on retinal RNA from E5-19 embryos and 6-week-old (adult) chickens (Fig. 10A). Reaction conditions were used that guaranteed that all samples were analyzed in the linear phase of amplification, which allowed the relative amount of each isoform within a sample to be determined unambiguously (see Methods). Transcripts encoding KD isoforms appeared elevated transiently in the retina at E5 (Fig. 10A,top panels), whereas $\mathrm{TK}+$ transcripts barely were detectable between E5 and E9 (Fig. $10 A$, middle panels). Both $\mathrm{TK}+$ and $\mathrm{KD}$ transcripts increased between E11 and hatching, although at 6 weeks posthatching (Fig. $10 A, A d), \mathrm{TK}+$ transcripts were reduced, whereas KD transcripts remained elevated. Northern blot analysis of TrkB mRNA expression confirmed the low-level expression of TK + transcripts early in development and their upregulation during the period of RGC death, E11 to E17 (data not shown). The developmental regulation of individual isoforms was assessed by measuring the relative expression of the TK+ or KD isoforms at each age. Throughout retinal development, the $\mathrm{T} 1$ and $\mathbf{J} 2$ isoforms were the most prominent $\mathrm{KD}$ isoforms, and each represented $\sim 45 \%$ of all RTPCR products. Similarly, the contributions of the minor $\mathbf{J} 1+\mathbf{J} 2$ and $\mathrm{J} 1$ isoforms remained relatively unchanged throughout development at $<10 \%$ and $<5 \%$, respectively, of all $\mathrm{KD}$ products. Within the TK+ class, the FL isoform was the most abundant at all ages. The relative contributions of the ED and $\mathrm{J} 1$ isoforms declined slightly over embryonic development and represented $\sim 10$ and $5 \%$, respectively, of all $\mathrm{TK}+$ products at hatching.

\section{Developmental expression of TrkB receptor mRNA in the optic tectum}

RT-PCR analysis demonstrated that the optic tectum expresses both $\mathrm{TK}+$ and $\mathrm{KD}$ isoforms of the TrkB receptor (Fig. 10B). As in the retina, the expression of $\mathrm{KD}$ isoforms was relatively strong as early as E5, and the T1 and $\mathrm{J} 2$ isoforms were the most prominent, each representing $\sim 40 \%$ of all $\mathrm{KD}$ products (Fig. $10 B$, top panels). The $\mathrm{J} 1$ isoform remained a minor component $(<5 \%$ of all $\mathrm{KD}$ products), but the $\mathrm{J} 1+\mathrm{J} 2$ isoform increased severalfold during tectal development to reach $20 \%$ of all $\mathrm{KD}$ transcripts by hatching. Although blots were not probed for the T3 motif, there appears to be relatively little of this isoform in either the developing optic tectum or retina, because the combined hybridization signals for the $\mathbf{J} 1$ isoform (top row, middle panel) and the 
Figure 9. RT-PCR amplification of KD receptor isoforms from E13 chick brain RNA. Lanes 1-3, Brain total RNA was RT-PCR-amplified with the PCR+ and KD - primers. The Southern blot was hybridized with the ${ }^{32} \mathrm{P}$-labeled $E C$ probe (lane 1), followed by stripping and hybridization with the ${ }^{32} \mathrm{P}$-labeled $J 1$ oligo (lane 2 ), and then the ${ }^{32} \mathrm{P}$-labeled $J 2$ oligo (lane 3). The EC probe labels a band at $450 \mathrm{bp}$ and two broad bands centered at $\sim 525$ and 600 bp. Lanes 4-8, Control PCR amplification of some of the subcloned isoforms from the bands in lane 1 . The expected products are indicated on the left, and the molecular weight markers are indicated on the right.

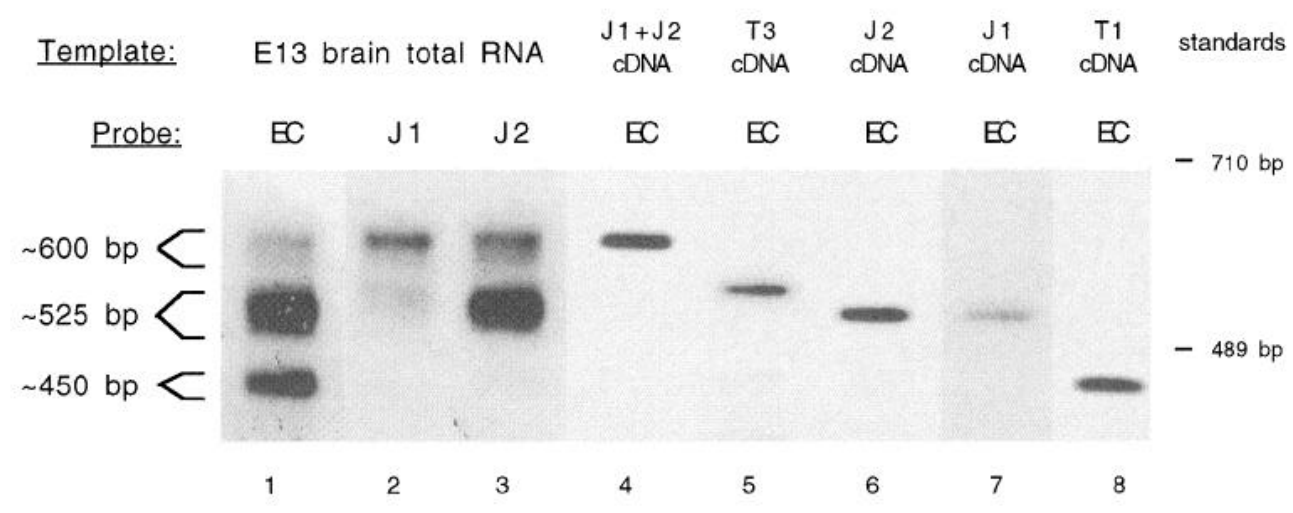

gene family. In contrast with the ED variants of FL mammalian TrkA and TrkC receptors (Meakin et al., 1992; Shelton et al., 1995), the avian ED motif was found in both KD and TK+ isoforms. Trk ED variants occur within the putative neurotrophinbinding domain (Perez et al., 1995; Urfer et al., 1995) and appear to be important for regulating ligand specificity, activation, or interaction with the p75 receptor (Benedetti et al., 1993). For example, TrkA receptors containing an ED motif display a significantly lower level of activation by NT3 (Clary and Reichardt, 1994). The avian TrkB ED isoform also appears to regulate ligand specificity, because NT3 activates the FL isoform, but not the ED isoform, when expressed in fibroblasts (K. L. Boeshore, A. S. Garner, T. H. Large, unpublished observations). However, low concentrations of NT3 fail to activate avian FL receptors expressed in PC12 cells, as has been found for mammalian TrkB receptors (Ip et al., 1993), indicating that other neuronal components such as the $\mathrm{p} 75$ receptor also may regulate ligand specificity.

Deletions and insertions of novel sequence into the cytoplasmic domain of Trk receptors are capable of altering cellular responses (Lamballe et al., 1993; Tsoulfas et al., 1993; Valenzuela et al., 1993; Garner and Large, 1994; Peng et al., 1995), presumably through altered coupling to signal transduction pathways. In contrast to the kinase domain insertions in TrkC receptors, a TK+ isoform of avian TrkB receptors contains the $\mathrm{J} 1$ insertion in the $\mathrm{JM}$ domain. Although its function is unknown, the $\mathrm{J} 1$ sequence displays homology with the $\mathrm{C}$ terminus of $\beta$-actin (Fig. $7 B$ ), which binds regulatory proteins such as $\alpha$-actinin and profilin (Schutt et al., 1993; Pollard et al., 1994). The J1 insert may regulate receptor subcellular localization (Schechter and Bothwell, 1981) or alter the local polymerization of actin (Theriot and Mitchison, 1993; Pollard et al., 1994). Conceivably, it may serve a more direct functional role by regulating profilin interaction with two important signaling pathways activated by Trk receptors, the ras (Theriot and Mitchison, 1993) and PLC- $\gamma$ pathways (GoldschmidtClermont et al., 1991).

TrkB receptors lacking the tyrosine kinase domain are the other major class of splice variant, although their function remains controversial. $\mathrm{KD}$ receptors may inhibit $\mathrm{TK}+$ receptor activity or

The presence of an 11 amino acid ED motif in avian receptors indicates that this is a conserved feature within the Trk 


\section{A. Retina}
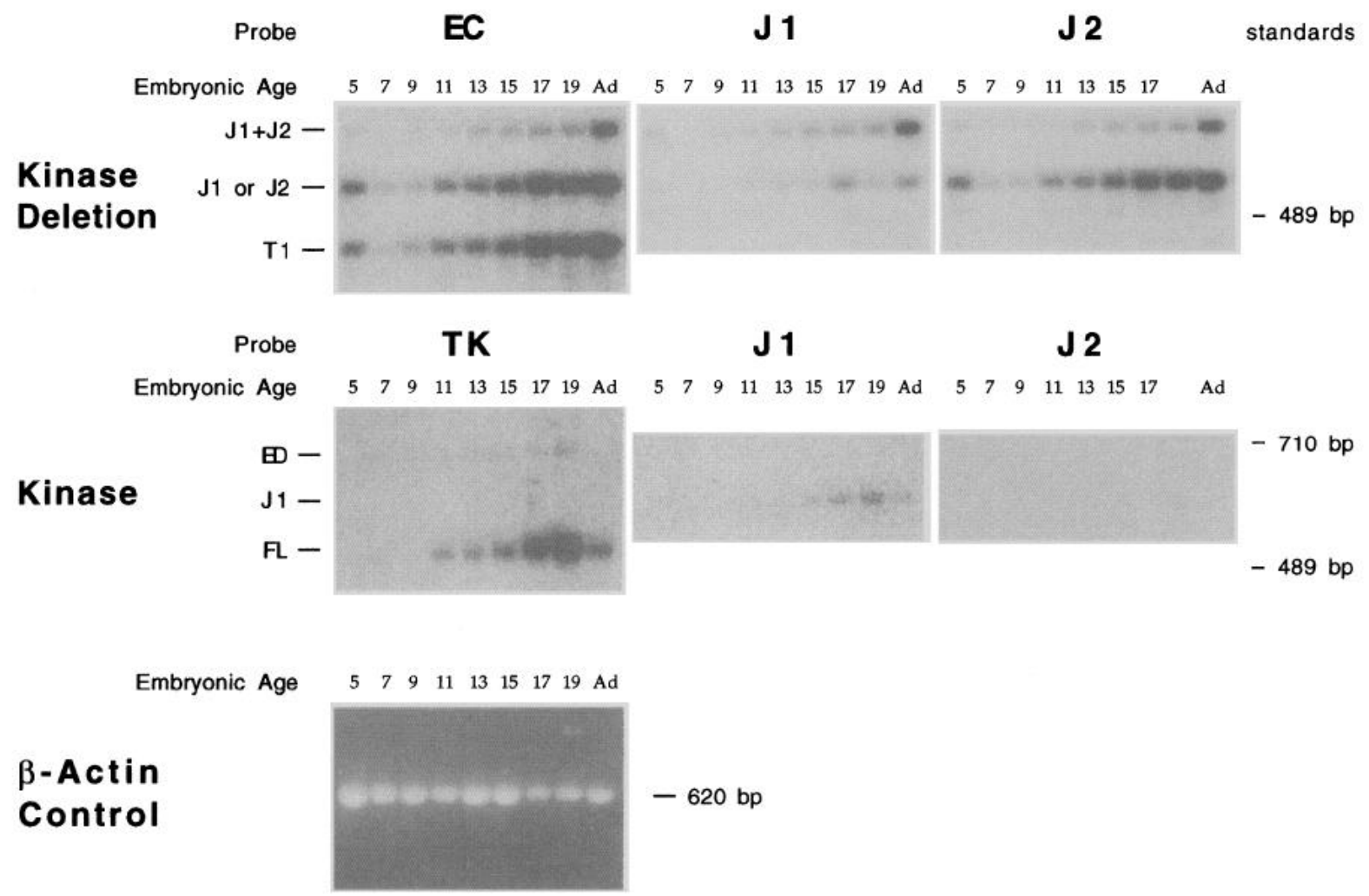

\section{B. Optic Tectum}

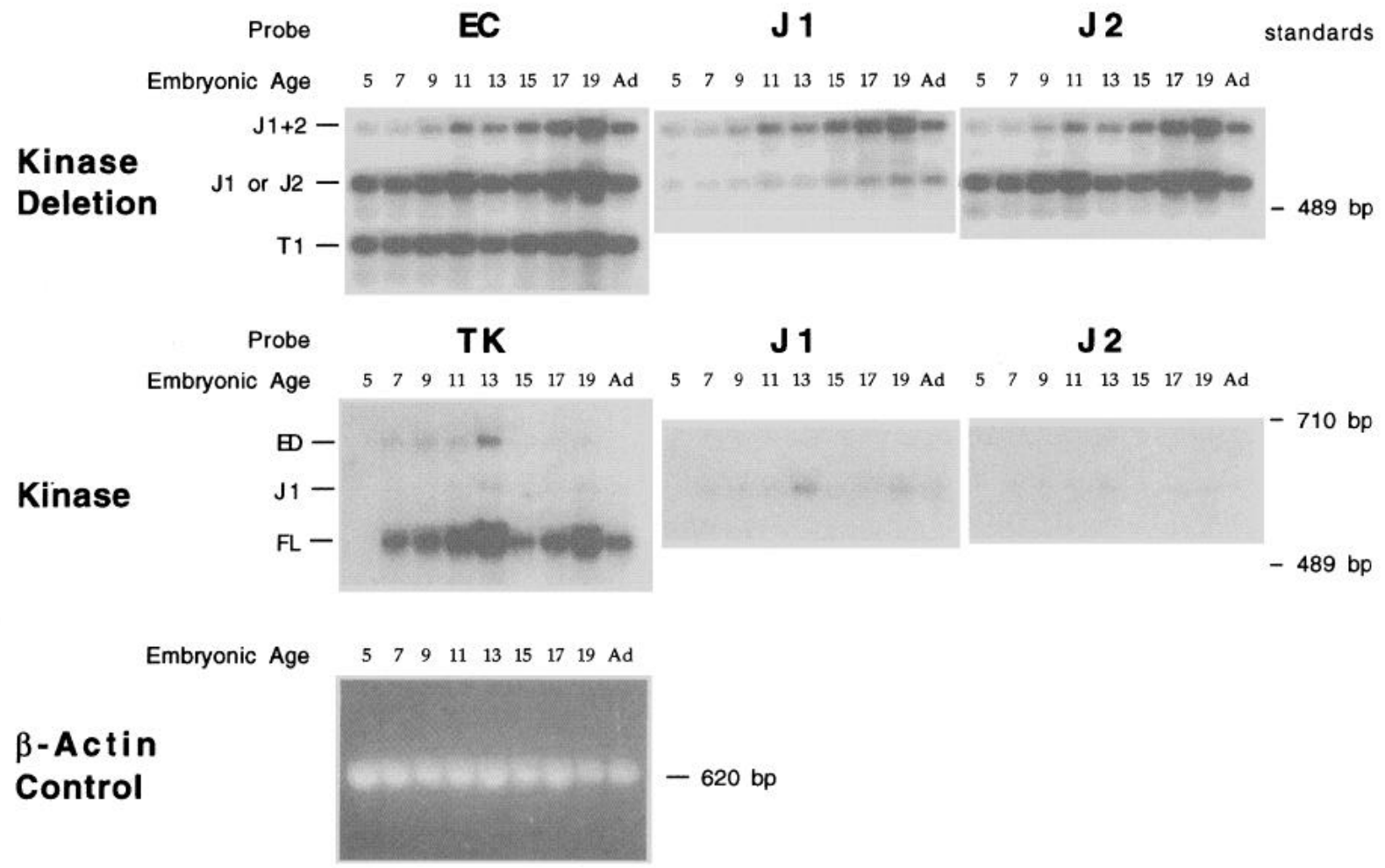


sequester ligand (Biffo et al., 1995; Garner and Large, 1993). The apparent predominance of the $\mathrm{T} 1$ motif in $\mathrm{KD}$ isoforms and the conservation of its coding sequence between mammals and birds argue for a common function, perhaps even stimulation of cytoplasmic signaling (Radeke et al., 1994). The finding that the J1 insert is shared by both $\mathrm{KD}$ and $\mathrm{TK}+$ isoforms suggests further that $\mathrm{KD}$ receptors possess functions in addition to simply binding ligands. Although RT-PCR has not been used to search for similar insertions in mammalian TrkB KD receptors, multiple truncated isoforms also have been identified by immunoprecipitation from neonatal rat brain (Knusel et al., 1994).

\section{TrkB mRNA expression in the retina}

A subpopulation of avian RGCs express TrkB mRNA, as was found in amphibian (Cohen-Cory and Fraser, 1994) and mammalian (Johnson et al., 1986) retinas, and expression began early in their differentiative program. Although the in situ probe could not differentiate between receptor isoforms, avian RGCs almost certainly express TK+ receptors, because RGCs are labeled with pan-Trk antibodies (Okazawa et al., 1994a), and large-diameter RGCs deprived of their tectal targets are rescued in vivo by BDNF (Voci et al., 1993) (see also Mey and Thanos, 1993; MansourRobaey et al., 1994). RT-PCR analysis identified an increase in $\mathrm{TK}+$ and $\mathrm{KD}$ isoforms at E11 that coincides with the ramification of RGC terminals in deeper tectal layers (Cantino and SistoDaneo, 1973; Rager, 1976) and the onset of RGC death (Hughes and McLoon, 1979). One mechanism for this increase may be increased access to tectal BDNF, which is elevated during this period in chick (Herzog et al., 1994) and frog (Cohen-Cory and Fraser, 1994), because exposure of central neurons to neurotrophins has been shown to increase Trk receptor expression (Holtzman et al., 1992). However, activity-dependent mechanisms also may regulate TrkB mRNA expression (also see Wong et al., 1995) (Birren et al., 1992), because light exposure increases TrkB mRNA in the adult avian retina (Okazawa et al., 1994b).

The expression of $\mathrm{KD}$ transcripts is surprisingly prominent in the retina at E5 and appears to be independent of retinotectal contact. KD isoforms also appear to predominate relative to $\mathrm{TK}+$ isoforms at E5 in the avian optic tectum as well as very early in rat brain development (Knusel et al., 1994). Because there is robust expression of BDNF mRNA in the retina at this time, $\mathrm{KD}$ receptors may be important for regulating early RGC differentiation. After a drop in expression after E5, the developmental incrcase in $\mathrm{KD}$ isoforms in the retina after E11 coincides roughly with the increase in TK + isoforms. This may serve to regulate the function of catalytic receptor isoforms, as proposed from studies of the developing mammalian brain (Allendoerfer et al., 1994; Escandon et al., 1994; Knusel et al., 1994). Surprisingly, immunoprecipitation experiments isolate TrkB KD receptors from E15 chicken lectum, but not retina (Escandon et al., 1994). Either the KD transcripts identified by RT-PCR are translated inefficiently in the retina at this age or $\mathrm{KD}$ receptors are transported preferentially to RGC axon terminals in the tectum.

\section{TrkB mRNA expression in the optic tectum}

Combined in situ hybridization and RT-PCR analyses indicate the presence of BDNF-responsive neurons in the tectum throughout most of embryonic development. Therefore, the immunoprecipitation of FL TrkB receptors from the embryonic optic tectum (Escandon et al., 1994) must be attributable to endogenous expression, at least in part, rather than simply to TrkB receptors located on RGC terminals. Unlike the retina, TK+ mRNA ex- pression was biphasic, with the first increase between E7 and E13 coinciding with a strong increase in tectal BDNF mRNA expression (Herzog et al., 1994). Although intrinsic mechanisms cannot be excluded, the increased expression may be related to the growth of RGC terminals across the superficial layer of the tectum during this period (Rager, 1976; Mey and Thanos, 1992). Indeed, retinal activity is capable of regulating tectal BDNF mRNA levels as early as E7 (Herzog et al., 1994), and coordinate regulation of BDNF and TrkB receptor mRNA has been observed in the mammalian brain after glutamate receptor activation (Wetmore et al., 1994; Dugich-Djordjevic et al., 1995).

The second phase of tectal expression of TK+ isoforms occurs after E13 and coincides with the formation of topographic and laminar-specific connections by RGC terminals and the onset of tectal dependence on retinal innervation for survival. The elevated BDNF mRNA levels in the retina and tectum (Herzog et al., 1994) raise the possibility of autocrine/paracrine and anterograde roles for BDNF/TrkB signaling, as has been proposed in other parts of the nervous system (Schecterson and Bothwell, 1992; Kokaia et al., 1993; Nishio et al., 1994; Acheson et al., 1995). Although retinal BDNF appears to act as a retrograde factor supporting ION neurons (von Bartheld et al., 1994), which strongly express TrkB receptors (Fig. $4 A$ ), retinal BDNF also may act locally. BDNF antibodies label a subpopulation of RGCs, and expression is not altered dramatically after optic stalk transection (Herzog and Barde, 1994). However, nearly all RGCs degenerate and die after axotomy, suggesting that RGC access to local BDNF is not sufficient to support their survival in the absence of tectal targets. Alternatively, retinal BDNF could serve as an anterograde factor regulating tectal neuron survival or function. In this regard, it will be important to characterize the expression pattern of the individual TrkB splice variants to determine whether different isoforms are coexpressed e.g., $\mathrm{TK}+$ and $\mathrm{KD}$, as is the case in the mammalian brain (Dugich-Djordjevic et al., 1995), or whether subpopulations of tectal neurons express distinct isoforms. However, there is indirect evidence for BDNF-responsive tectal neurons that is consistent with the in situ and RT-PCR results. Superficial SGF neurons appear to depend on the anterograde transport and release of trophic substances from RGC terminals (Catsicas et al., 1992), and BDNF injected into the eye is transported to the tectum, where it is capable of rescuing tectal neurons (von Bartheld et al., 1993; von Bartheld et al., 1995). RGCs also regulate in an activity-dependent manner the survival of deeper SGC neurons (Catsicas et al., 1992) and second-order neurons in the SpI that innervate the SGC (Reiner et al., 1982; Page et al., 1993). Because SGC neurons express TrkB and BDNF (von Bartheld et al., 1993) and SpL neurons express TrkB (Fig. 5), it is conceivable that $\mathrm{RGC}$ activity regulates the release of BDNF by SGC neurons (also see Ghosh et al., 1994) (Acheson et al., 1995), which then acts to support SGC neurons in an autocrine manner and $\mathrm{SpL}$ neurons in a retrograde manner.

In addition to survival effects, there is a growing appreciation of the potential for the neurotrophins to regulate synaptic activity, an important determinant of both connectivity patterns during development and plasticity in the adult (Crair and Malenka, 1995; Kirkwood et al., 1995). TrkB transcripts are expressed in several nuclei of the avian visual system (Fig. 5) that receive patterned inputs from the retina [tectum, ION, lateroventral geniculate nuclcus, internal laycr (LGv:il), dorsal lateral geniculate, superficial magnocellular (SM)], suggesting that BDNF/TrkB signaling may help coordinate the normal development of topographic connections (Cabelli et al., 1995). Similarly, nuclei in feedback 
pathways [ION, nucleus isthmus, (NI), LGv, SpL] are potential sites of regulation of visual information (Fig. 5) and may require BDNF/TrkB signaling to remain plastic (Lohof et al., 1993; Kang and Schuman, 1995). Thus, BDNF/TrkB signaling is likely to play a major role in both the formation and normal function of the visual system.

\section{REFERENCES}

Acheson A, Conover JC, Fandl JP, DeChiara TM, Russell MP, Thadani A, Squinto SP, Yancopoulos GD, Lindsay RM (1995) ^ BDNF autocrine loop in adult sensory neurons prevents cell death. Nature 374:450-453.

Allendoerfer KL, Cabelli RJ, Escandon E, Kaplan DR, Nikolics K, Shatz CJ (1994) Regulation of neurotrophin receptors during the maturation of the mammalian visual system. J Neurosci 14:1795-1811.

Barbacid M (1994) The Trk family of neurotrophin receptors. J Neurobiol 25:1386-1403.

Benedetti M, Levi A, Chao MV (1993) Differential expression of nerve growth factor receptors leads to altered binding affinity and neurotrophin responsiveness. Proc Natl Acad Sci USA 90:7859-7863.

Biffo S, Carter B, Offenhauser N, Barde Y-A (1995) Truncated TrkB restricts BDNF availability during development: expression pattern and biochemical properties. Soc Neurosci Abstr 21:1060.

Birren SJ, Verdi JM, Anderson DJ (1992) Membrane depolarization induces p140trk and NGF responsiveness, but not p75 LNGFR, in MAH cells. Science 257:395-397.

Cabelli RJ, Hohn A, Shatz CJ (1995) Inhibition of ocular dominance column formation by infusion of NT-4/5 or BDNF. Science 267:1662-1666.

Cantino D, Sisto-Daneo L (1973) Synaptic junctions in the developing chick optic tectum. Experientia 29:85-87.

Catsicas M, Pequignot Y, Clarke PGH (1992) Rapid onset of neuronal death induced by blockade of either axoplasmic transport or action potentials in afferent fibers during brain development. J Neurosci 12:4642-4650.

Chomczynski P (1992) One hour downward alkaline capillary transfer for blotting of DNA and RNA. Anal Biochem 201:134-139.

Clarke PGH, Rogers LA, Cowan WM (1976) The time of origin and the pattern of survival of neurons in the isthmo-optic nucleus of the chick. J Comp Neurol 167:125-141.

Clarke PGH (1985) Neuronal death during development in the isthmooptic nucleus of the chick: sustaining role of afferents from the tectum. J Comp Neurol 234:365-379.

Clarke PGH (1992) Neuron death in the developing avian isthmo-optic nucleus, and its relation to the establishment of functional circuitry. J Neurobiol 23:1140-1158.

Clary DO, Reichardt LF (1994) An alternatively spliced form of the nerve growth factor receptor TrkA confers an enhanced response to neurotrophin 3. Proc Natl Acad Sci USA 91:11133-11137.

Cohen-Cory S, Fraser SE (1994) BDNF in the development of the visual system of Xenopus. Neuron 12:747-761.

Crair MC, Malenka RC (1995) A critical period for long-term potentiation at thalamocortical synapses. Nature 375:325-328.

Dechant G, Biffo S, Okazawa H, Kolbeck R, Pottgiesser J, Barde Y-A (1993) Expression and binding characteristics of the BDNF receptor chick TrkB. Development 119:545-558.

Drescher U, Kremoser C, Handwerker C, Loschinger J, Noda M, Bonhoeffer $F$ (1995) In vitro guidance of retinal ganglion cell axons by RAGS, a $25 \mathrm{kDa}$ tectal protein related to ligands for Eph receptor tyrosine kinase. Cell 82:359-370.

Dugich-Djordjevic MM, Ohsawa F, Okazaki T, Mori N, Day JR, Beck KD, Hefti F (1995) Differential regulation of catalytic and non-catalytic trkB $\mathrm{mRNA}$ in the rat hippocampus following seizures induced by systemic administration of kainate. Neuroscience 66:861-877.

Ehrlich D, Mark R (1984) An atlas of the primary visual projections in the brain of the chick Gallus gallus. J Comp Neurol 223:592-610.

Escandon E, Soppet D, Rosenthal A, Mendoza-Ramirez J-L, Szonyi E, Burton LE, Henderson CE, Parada LF, Nikolics K (1994) Regulation of neurotrophin receptor expression during embryonic and postnatal development. J Neurosci 14:2054-2068.

Garner AS, Large TH (1993) Alternate splicing of the trkC tyrosine kinase dissociates process outgrowth from survival. Soc Neurosci Abstr $19: 1477$.
Garner AS, Large TH (1994) Isoforms of the avian TrkC receptor: a novel kinase insertion dissociates transformation and process outgrowth from survival. Neuron 13:457-472.

Ghosh A, Carnahan J, Greenberg ME (1994) Requirement for BDNF in activity-dependent survival of cortical neurons. Science 263:1618-1623.

Golde TE, Estus S, Usiak M, Younkin LH, Younkin SG (1990) Expression of $\beta$-amyloid protein precursor mRNAs: recognition of a novel alternatively spliced form and quantitation in Alzheimer's Disease using PCR. Neuron 4:253-267.

Goldschmidt-Clermont PJ, Kim JW, Machesky LM, Rhee SG, Pollard TD (1991) Regulation of phospholipase $\mathrm{C} \gamma$ by profilin and tyrosine phosphorylation. Science 251:1231-1233.

Guillemot F, Cepko CL (1992) Retinal fate and ganglion cell differentiation are potentiated by acidic FGF in an in vitro assay of early retinal development. Development 114:743 754 .

Hamburger V, Hamilton H (1951) A series of normal stages in the development of the chick embryo. J Morphol 88:49-92.

Herzog K-H, Barde Y-A (1994) BDNF mRNA levels in the chick optic tectum are regulated by neurotransmitters during synaptogenesis. Soc Neurosci Abstr 20:1304

Herzog K-H, Bailey K, Barde Y-A (1994) Expression of the BDNF gene in the developing visual system of the chick. Development 120:1643-1649.

Holtzman DM, Li Y, Parada LF, Kinsman S, Chen CK, Valletta JS, Zhou J, Long JB, Mobley WC (1992) p140trk mRNA marks NGFresponsive forebrain neurons: evidence that trk gene expression is induced by NGF. Neuron 9:465-478.

Horikoshi T, Danenberg KD, Stadlbauer THW, Volkenandt M, Shea LC, Aigner K, Gustavsson B, Leichman L, Frosing R, Ray M, Gibson NW, Spears CP, Danenberg PV (1992) Quantitation of thymidylate synthase, dihydrofolate reductase, and DT-diaphorase gene expression in human tumors using the polymerase chain reaction. Cancer Res 52:108-116.

Hughes WF, McLoon SC (1979) Ganglion cell death during normal retinal development in the chick: comparisons with cell death induced by early target field destruction. Exp Neurol 66:587-601.

Hunt SP, Kunzle H (1976) Observations on the projections and intrinsic organization of the pigeon optic tectum: an autoradiographic study based on anterograde and retrograde axonal and dendritic flow. J Comp Neurol 170:153-172.

Ip NY, Stitt TN, Tapley P, Klein R, Glass DJ, Fandl J, Greene LA, Barbacid M, Yancopoulos GD (1993) Similarities and differences in the way neurotrophins interact with the Trk receptors in neuronal and nonneuronal cells. Neuron 10:137-149.

Jelsma TN, Friedman HH, Berkelaar M, Bray GM, Aguayo AJ (1993) Different forms of the neurotrophin receptor TrkB mRNA predominate in rat retina and optic nerve. $J$ Neurobiol 24:1207-1214.

Johnson JE, Barde Y-A, Schwab M, Thoenen H (1986) Brain-derived neurotrophic factor supports the survival of cultured rat retinal ganglion cells. J Neurosci 6:3031-3038.

Kahn AJ (1973) Ganglion cell formation in the chick neural retina. Brain Res 63:285-290.

Kang H, Schuman EM (1995) Long-lasting neurotrophin-induced enhancement of synaptic transmission in the adult hippocampus. Science 267:1658-1662.

Kelly JP, Cowan WM (1972) Studies on the development of the chick optic tectum. III. Effects of early eye removal. Brain Res 42:263-288.

Kirkwood A, Lee H-K, Bear MF (1995) Co-regulation of long-term potentiation and experience-dependent synaptic plasticity in visual cortex by age and experience. Nature 375:328-331.

Klein R, Conway D, Parada LF, Barbacid M (1990) The trkB tyrosine protein kinase gene codes for a second neurogenic receptor that lacks the catalytic kinase domain. Cell 61:647-656.

Knusel B, Rabin SJ, Hefti F, Kaplan DR (1994) Regulated neurotrophin receptor responsiveness during neuronal migration and early differentiation. J Neurosci 14:1542-1554.

Kokaia Z, Bengzon J, Metsis M, Kokaia M, Persson H, Lindvall O (1993) Coexpression of neurotrophins and their receptors in neurons of the central nervous system. Proc Natl Acad Sci USA 90:6711-6715.

Lamballe F, Tapley P, Barbacid M (1993) TrkC encodes multiple neurotrophin-3 receptors with distinct biological properties and substrate specificities. EMBO J 12:3083-3094.

Large TH, Rauh JJ, DeMello FG, Klein WL (1985) Two molecular weight forms of muscarinic acetylcholine receptors in the avian central 
nervous system: switch in predominant form during differentiation of synapses. Proc Natl Acad Sci USA 82:8785-8789.

Large TH, Weskamp G, Helder JC, Radeke MJ, Misko TP, Shooter EM, Reichardt LF (1989) Structure and developmental expression of the nerve growth factor receptor in the chicken central nervous system. Neuron 2:1123-1134.

LaVail JH, Cowan WM (1971) The development of the chick optic tectum. I. Normal morphology and cytoarchitectonic development. Brain Res 28:391-419.

Lohof AM, Ip NY, Poo MM (1993) Potentiation of developing neuromuscular synapses by the neurotrophins NT-3 and BDNF. Nature $363: 350-353$.

Mansour-Robaey S, Clarke DB, Wang Y-C, Bray GM, Aguayo AJ (1994) Effects of ocular injury and administration of brain-derived neurotrophic factor on survival and regrowth of axotomized retinal ganglion cells. Proc Natl Acad Sci USA 91:1632-1636.

Meakin SO, Suter U, Drinkwater CC, Welcher AA, Shooter EM (1992) The rat trk protooncogene product exhibits properties characteristic of the slow nerve growth factor receptor. Proc Natl Acad Sci USA 89:2374-2378.

Mey J, Thanos S (1992) Development of the visual system of the chick-a review. J Hirnforsch 33:673-702.

Mey J, Thanos S (1993) Intravitreal injections of neurotrophic factors support the survival of axotomized retinal ganglion cells in adult rats in vivo. Brain Res 602:304-317.

Middlemas DS, Lindberg RA, Hunter T (1991) TrkB, a ncural receptor protein-tyrosine kinase: evidence for a full-length and two truncated receptors. Mol Cell Biol 11:143-153.

Nishio T, Furukawa S, Akiguchi I, Oka N, Ohnishi K, Tomimoto H, Nakamura S, Kimura J (1994) Cellular localization of nerve growth factor-like immunoreactivity in adult rat brain: quantitative and immunohistochemical study. Neuroscience 60:67-84.

Okazawa H, Nishiyama K, Kamei M, Washizaki K, Murayama S, Kwak S, Kanazawa I (1994a) Trk immunoreactivity at neuronal dendrite and cell body. Biochem Biophys Res Commun 194:683-690.

Okazawa H, Kamei M, Imafuku I, Kanazawa I (1994b) Gene regulation of TrkB and TrkC in the chick retina by light/darkness exposure. Oncogene 9:1813-1818.

Page TP, Jaboro NG, Crossland WJ (1993) Retrograde transneuronal degencration in a basal ganglia targct, the latcral spiriform nucleus, induced by anterograde transneuronal degeneration following eye removal in the chicken. Exp Neurol 119:120-127.

Peng X, Greene LA, Kaplan DR, Stephens RM (1995) Deletion of a conserved juxtamembrane sequence in trk abolishes NGF-promoted neuritogenesis. Neuron 15:395-406.

Perez P, Coll PM, Hempstead BL, Martin-Zanca D, Chao MV (1995) NGF binding to the trk tyrosine kinase receptor requires the extracellular immunoglobulin-like domains. Mol Cell Neurosci 6:97-105.

Pollard TD, Almo S, Quirk S, Vinson V, Lattman EE (1994) Structure of actin binding proteins: insights about function at atomic resolution. Annu Rev Cell Biol 10:207-249.

Radeke MJ, Baxter G, Kuo R, Medina-Selby A, Coit D, Valenzuela P, Feinstein SC (1994) Signal transduction by the truncated TrkB isoform T1. Soc Neurosci Abstr 20:37.

Rager GH (1976) Morphogenesis and physiogenesis of the retino-tectal connection in the chicken. II. The retino-tectal synapses. Proc R Soc Lond [Biol] 192:353-370.

Rager GH, Rager U (1978) Systems-matching by degeneration. I. A quantitative electron microscopic study of the generation and degeneration of retinal ganglion cells in the chicken. Exp Brain Res 33:65-78.

Rager GH, von Oeynhausen B (1979) Ingrowth and ramification of retinal fibers in the developing optic tectum of the chick embryo. Exp Brain Res 35:213-227.

Rager GH (1980) Development of the retinotectal projection in the chicken. Adv Anat Embryol Cell Biol 63:1-92.

Reh TA, Tully T (1986) Regulation of tyrosine hydroxylase-containing amacrine cell number in larval frog retina. Dev Biol 114:463-469.

Reiner A, Brecha NC, Karten IIJ (1982) Basal ganglia pathways to the tectum: the afferent and efferent connections of the lateral spiriform nucleus of pigeon. J Comp Neurol 208:16-36.
Rodriguez-Tebar A, Jeffrey PL, Thoenen H, Barde Y-A (1989) The survival of chick retinal ganglion cells in response to brain-derived neurotrophic factor depends on their embryonic age. Dev Biol 136:296-303.

Saiki RK, Gelfand DH, Stoffel S, Scharf SJ, Higuchi R, Horn GT, Mullis KB, Erlich HA (1988) Primer directed enzymatic amplification of DNA with a thermostable DNA polymerase. Science 239:487-491.

Schaeren-Wiemers N, Gerfin-Moser A (1993) A single protocol to detect transcripts of various types and expression levels in neural tissues and cultured cells: in situ hybridization using digoxigenin-labeled cRNA probes. Histochem J 100:431-440.

Schechter AL, Bothwell MA (1981) Nerve growth factor receptors on PC12 cells: evidence for two receptor classes with differing cytoskeleton association. Cell 24:867-874.

Schecterson LC, Bothwell M (1992) Novel roles for neurotrophins are suggested by BDNF and NT-3 mRNA expression in developing neurons. Neuron 9:449-463.

Schutt CE, Myslik JC, Rozycki MD, Goonsekere NC, Lindberg U (1993) The structure of crystalline profilin- $\beta$-actin. Nature 365:810-816.

Shelton DL, Sutherland J, Gripp J, Camerato T, Armanini MP, Phillips HS, Carroll K, Spencer SD, Levinson AD (1995) Human trks: molecular cloning, tissue distribution, and expression of extracellular domain immunoadhesins. J Neurosci 15:477-491.

Takahashi JB, Hoshimaru M, Kikuchi H, Hatanaka M (1993) Developmental expression of trkB and low-affinity NGF receptor in the rat retina. Neurosci Lett 151:174-177.

Thanos S, Bonhoeffer F (1983) Investigations on the development and topographic order of retinotectal axons: anterograde and retrograde staining of axons and perikarya with rhodamine in vivo. J Comp Neurol 219:420-430.

Thanos S, Bonhoeffer F (1987) Axonal arborization in the developing chick retinotectal systcm. J Comp Neurol 261:155-164.

Theriot JA, Mitchison TJ (1993) The three faces of profilin. Cell 75:835-838.

Tsoulfas P, Soppet D, Escandon E, Tessarollo L, Mendoza-Ramirez J-L, Rosenthal A, Nikolics K, Parada LF (1993) The rat trkC locus encodes multiple neurogenic receptors that exhibit differential response to neurotrophin-3 in PC12 cells. Neuron 10:975-990.

Turner DL, Snyder EY, Cepko CL (1990) Lineage-independent determination of cell type in the embryonic mouse retina. Neuron 4:833-845.

Urfer R, Tsoulfas P, O'Connell L, Shelion DL, Parada LF, Presta CG (1995) An immunoglobulin-like domain determines the specificity of neurotrophin receptor. EMBO J 14:2795-2805.

Valenzuela DM, Maisonpierre PC, Glass DJ, Rojas E, Nunez L, Kong Y, Gies DR, Stitt TN, Ip NY, Yancopoulos GD (1993) Alternative forms of rat TrkC with different functional capabilities. Neuron 10:963-974.

Voci JM, McKeon RJ, Large TH (1993) Retroviral delivery of neurotrophin genes into embryonic chick retina. Soc Neurosci Abstr 19:722.

von Bartheld CS, Schecterson LC, Bothwell M (1993) Retrograde and anterograde transport of neurotrophins from the eye to the brain in chick embryos. Soc Neurosci Abstr 19:1101.

von Bartheld CS, Kinoshita Y, Prevette D, Yin Q-W, Oppenheim RW, Bothwell M (1994) Positive and negative effects of neurotrophins on the isthmo-optic nucleus in chick embryos. Neuron 12:639-654.

von Bartheld CS, Byers MR, Williams R, Bothwell M (1995) Anterograde transport and axo-dendritic transfer of neurotrophins in the developing visual system. Soc Neurosci Abstr 21:1300.

Wetmore C, Olson L, Bean AJ (1994) Regulation of BDNF expression and release from hippocampal neurons is mediated by non-NMDA type glutamate receptors. J Neurosci 14:1688-1700.

Wetts R, Fraser SE (1988) Multipotent precursors can give rise to all major cell types in the frog retina. Science 239:1142-1145.

Wong ROL, Chernjavsky A, Smith SJ, Shatz CJ (1995) Early functional ncural nctworks in the devcloping retina. Nature 374:716-718.

Xie X-Y, Garner AS, Voci JM, Large TH (1992) Neurotrophin expression in the developing chick retina. Soc Neurosci Abstr 18:1289. 